\title{
Effects of Pre-Harvest Methyl Jasmonate Treatments on Fruit Quality of Fuji Apples during Cold Storage
}

\author{
Erdal Ağlar ${ }^{1 *} \quad$ Burhan Öztürk ${ }^{2}$ \\ ${ }^{1}$ Suşehri Timur Karabal Vocational School, Cumhuriyet University, Suşehri, Sivas, Turkey \\ ${ }^{2}$ Department of Horticulture, Faculty of Agriculture, Ordu University, Ordu, Turkey
}

Received: 15.12.2017 Accepted: 22.02.2018

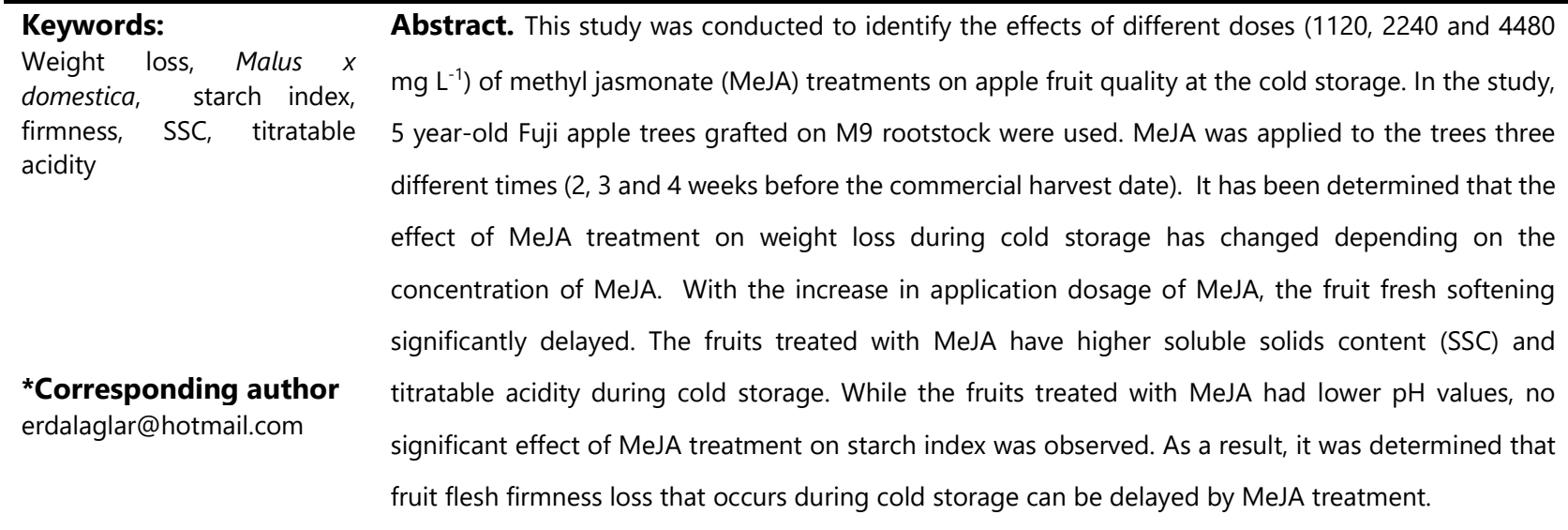

\section{Hasat Öncesi Metil Jasmonat Uygulamalarının Soğukta Muhafaza Süresince Fuji Elmasının Meyve Kalitesi Üzerine Etkisi}

\begin{tabular}{|c|c|}
\hline Anahtar kelimeler: & Özet. Araştırma hasat öncesi farklı dozlarda uygulanan $\left(1120,2240\right.$ ve $\left.4480 \mathrm{mg} \mathrm{L}^{-1}\right)$ metil jasmonatın \\
\hline \multirow{8}{*}{$\begin{array}{l}\text { Ağırlık kaybı, Malus } x \\
\text { domestica, nişasta indeksi, } \\
\text { sertlik, SÇKM, titre edilebilir } \\
\text { asitlik }\end{array}$} & $\begin{array}{l}\text { (MeJA) soğukta muhafaza süresince Fuji elmasının meyve kalite özellikleri üzerine olan etkilerini } \\
\text { belirlemek için yürütülmüştür. Araştırmada, M9 anacı üzerine aşılı } 5 \text { yaşlı Fuji elma ağaçları kullanılmıştır. }\end{array}$ \\
\hline & MeJA, 3 farklı zamanda (ticari hasattan 2, 3, ve 4 hafta önce) ağaçlara uygulanmıştır. Soğukta muhafaza \\
\hline & süresince ağırlık kaybı üzerine MeJA'nın etkisinin uygulama dozuna bağlı olarak değiştiği tespit edilmiştir. \\
\hline & MeJA uygulama dozu arttıkça, meyve etinde meydana gelen yumuşama önemli derecede geciktirilmiştir. \\
\hline & Depolama süresince, MeJA ile muamele olan meyvelerin SÇKM ve asitlik içeriği daha yüksek bulunmuştur. \\
\hline & MeJA ile muamele olmuş meyvelerin pH değeri düşük olmasına rağmen, nişasta indeksi üzerine MeJA \\
\hline & uygulamalarının önemli bir etkisi gözlemlenmemiştir. Sonuç olarak, soğukta muhafaza süresince meyve \\
\hline & i sertliğinde meydana gelen kaybın MeJA uygulaması ile geciktirilebileceği belirlenmişstir. \\
\hline
\end{tabular}




\section{INTRODUCTION}

Apple is one of the fruit species that have the highest world production. Due to its fruit qualities and the fact that it can be cultivated in many regions of Turkey, apple is prefered and consumed by the consumers throughout the year. Consumption of apples year round is possible with high-quality fruits at harvest and post-harvest storage. As with many fruit species, it is very important to maintain post-harvest quality of apple and to provide continuous supply in the market. Apple can be stored for a longer time due to its fruit characteristics. But it is not possible to maintain fruit quality as it is untill the end of cold storage. In this sense, it is important to minimize fruit quality losses that occur during cold storage.

The quality losses, which occur at the cold storage, can be reduce by the preharvest (Zhang and Whitting 2011; Einhorn et al., 2013; Gimenez et al., 2014; Martinez-Espla et al., 2014; Valverde et al., 2015) and postharvest (Petracek et al., 2002; Valero et al., 2011; Giacalone and Chiabrando 2013; Valero et al., 2014) applications.

The pre-harvest treatments improve fruit quality and have positive effects at the cold storage, while post-harvest treatments prevent potential losses in fruits during cold storage (Meheriuk et al., 1995).

Due to the development of resistance by pathogens to some fungicides and food safety and environmental pollution, the alternative measures was developed in controling of diseases at cold storage (Ragsdale and Sisler 1994). Therefore, pre-harvest treatments that can increase fruit firmness and protect fruit against diseases that may occur after harvest are in the foreground.

Previous researchers tried to reduce these postharvest losses with different growth regulators like aminoethoxyvinylglycine (Öztürk et al., 2017), gibberellic acid (Ozkan et al., 2016), methyl salicylate (Valverde et al., 2015), lysophosphatidylethanolamine (LPE) (Özgen et al., 2015), salicylic acid (Gimenez et al., 2015, 2017), Aloe vera (Castillo et al., 2010) and methyl jasmonate (Kucuker and Ozturk 2015). Methyl jasmonate (MeJA), elicitor or signalling agent involved in many physiological and biochemical processes, exists naturally in a wide range of higher plants (Creelman and Mullet 1997). It has been reported that postharvest MeJA treatment has reduced the number of stress-induced injuries during cold storage, such as chilling injury, mechanical and salt stress (Pena-Cortes et al., 2005; Sayyari et al., 2011).
It has been determined that MeJA treatment suppressed fungal decay, for example, grey mold rot in strawberry (Moline et al., 1997), and anthracnose in tomato (Tzortzakis 2007) and loquat fruit (Cao et al., 2008). Yao and Tian (2005) have determined that preharvest MeJA treatments reduce fungal infections caused by Monilinia fructicola on sweet cherry. It has also been reported that the pre-harvest MeJA treatment delayed the softening of fruit during storage (Rudell et al., 2005). The studies with MeJA generally focus on postharvest treatments and the fruit firmness mechanism.

There are very few studies on pre-harvest MeJA treatments and their effects on harvested and postharvest storage fruit quality. In this study, which had been carried out by considering this situation, the effects of pre-harvest MeJA treatments on the fruit quality during harvest and after harvest and on losses occur at cold storage have been evaluated.

\section{MATERIALS AND METHODS}

\section{Plant Material and Experimental Design}

The study carried out with five year-old Fuji trees grafted on M9 rootstock was laid out as three replicates according to randomized plots trial design and there were 4 trees in each replicate. Cultural practices such as irrigation, fertilization, pruning and thinning were carried out on the trees. The trees were trained as slender spindle training system. Irrigation was carried out with double-line drip irrigation system with plumbing irrigation pipes positioned at $20 \mathrm{~cm}$ intervals giving 2 liters of water per hour. The study consisted of four treatments: three different concentrations of MeJA $\left(1120,2240\right.$ and $\left.4480 \mathrm{mg} \mathrm{L}^{-1}\right)$ and control $\left(0 \mathrm{mg} \mathrm{L}^{-1}\right)$. The treatments of MeJA were applied repetitively at three different times: 2, 3 and 4 weeks before commercial harvest date. During the commercial harvest, $10 \mathrm{~kg}$ of fruit was harvested for each repetition and $3 \mathrm{~kg}$ of fruit $(1 \mathrm{~kg}$ for each repetition) was allocated for each analysis period. The fruit was harvested by hand and injured, diseased or harmed fruits were removed.

Besides measurements made during harvest, additional measurements were performed in $2^{\text {nd }}, 4^{\text {th }}$ and $6^{\text {th }}$ months. All fruits were stored at $0^{\circ} \mathrm{C}$ and $90 \pm 5 \%$ RH for 6 months in the same storage which has normal atmosphere conditions, and quality analysis and measurements were made in 60-days intervals. 


\section{Weight Loss}

Fruit weights were determined using a digital scale $( \pm 0.01 \mathrm{~g})$ (Radvag PS $4500 / C / 1$, Poland). Weight loss was determined by the difference between the initial and final weights of each replicate during cold storage and expressed as percent.

\section{Fruit Flesh Firmness}

After the fruit peel has been removed by a cutting tool, flesh firmness (five fruits) was measured on three sides of equatorial line of each fruit using a pressmounted penetrometer (FT-327 MoCormick Fruit Tech., Yakima, ABD) with $11.1 \mathrm{~mm}$ tip. The values measured are expressed as Newton $(\mathrm{N})$.

\section{Solible Solids Content, pH and Titratable Acidity}

A sample of juice was taken from one piece of each of ten fruits per tree, and 3 different measurements were obtained from each replication. SSC was determined with a digital refractometer (PAL- 1, McCormick Fruit Tech., Yakima, Wash) and the values had been expressed as \% ( ${ }^{\circ}$ Brix). For titratable acidity (TA), $10 \mathrm{~mL}$ of extract was taken from each sample, 10 $\mathrm{mL}$ distilled water was added and the value corresponding to consumed sodium hydroxide $(\mathrm{NaOH})$ during the titration with $0.1 \mathrm{~N} \mathrm{NaOH}$ to increase the $\mathrm{pH}$ of samples to 8.1 was expressed in malic acid (g malic acid $100 \mathrm{~mL}^{-1}$ ).

\section{Starch Index}

Samples whose fruit firmness was measured were divided into 2 equal parts and a circular slice about 1 $\mathrm{cm}$ thick was taken from the remaining part of the stem side and $0.5 \%$ iodized potassium iodide (IKI) solution was sprayed to the circular slice until it was completely wetted.

After about 5 minutes, the area containing the starch was stained dark blue and values were given according to the scales (1-8 scale interval, $1=100 \%$ blue painted, $8=100 \%$ starch turned into sugar) that the investigators (Blanpied and Silsby 1992) had prepared.

\section{Statistical Analysis}

The experiment was set up in 3 replications according to randomized plot trial design and there were 4 trees in each repetition and 48 trees were used in total. All statistical analyses were performed with SAS Version 9.3 (SAS Institute Inc., Cary, NC, USA). Data were analyzed by analysis of variance. Mains of treatments were separated by Duncan's multiple range tests at a significance level of 0.05 .

\section{RESULTS}

\section{Weight Loss}

Considering the storage times, the fruit weight loss increased in proportion to the cold storage time. It has been determined that the effect of MeJA on weight loss depends on concentration and cold storage times. On the $60^{\text {th }}$ day of the cold storage, while $4480 \mathrm{mg} \mathrm{L}^{-1}$ MeJA treatment did not affect weight loss, $1120 \mathrm{mg} \mathrm{L}^{-}$ ${ }^{1}$ MeJA treatment led to an increasing in weight loss and $2240 \mathrm{mg} \mathrm{L}^{-1}$ MeJA treatment led to a decrease in weight loss. On the $120^{\text {th }}$ and $180^{\text {th }}$ day of storage, it has been observed that weight losses in control and $2240 \mathrm{mg} \mathrm{L}^{-1} \mathrm{MeJA}$ treatment were at the similar levels, whereas $1120 \mathrm{mg} \mathrm{L}^{-1}$ MeJA and $4480 \mathrm{mg} \mathrm{L}^{-1}$ MeJA doses increased weight loss (Table 1).

Table 1. Effects of pre-harvest MeJA treatments on weight loss of Fuji apples.

Çizelge 1. Fuji elmasının ağırlık kaybı üzerine hasat öncesi MeJA uygulamalarinin etkisi.

\begin{tabular}{lccc}
\hline \multirow{2}{*}{ MeJA treatments } & \multicolumn{3}{c}{ Weight loss (\%) } \\
\cline { 2 - 4 } & $\mathbf{6 0}$ & $\mathbf{1 2 0}$ & $\mathbf{1 8 0}$ \\
\hline Control (0 $\left.\mathbf{~ m ~ L ~ L}^{-1}\right)$ & $0.98 \mathrm{~b}$ & $1.53 \mathrm{~b}$ & $2.15 \mathrm{~b}$ \\
$\mathbf{1 1 2 0} \mathbf{~ m g ~ L}^{-1} \mathbf{~ M e J A}$ & $1.53 \mathrm{a}$ & $2.40 \mathrm{a}$ & $3.27 \mathrm{a}$ \\
$\mathbf{2 2 4 0} \mathbf{~ m g ~ L}^{-1} \mathbf{M e J A}$ & $0.65 \mathrm{c}$ & $1.44 \mathrm{~b}$ & $2.09 \mathrm{~b}$ \\
$\mathbf{4 4 8 0} \mathbf{~ m g ~ L}^{-1} \mathbf{M e J A}$ & $1.16 \mathrm{~b}$ & $2.17 \mathrm{a}$ & $2.98 \mathrm{a}$ \\
\hline
\end{tabular}

The means with the same letter do not differ according to Duncan's multiple range test, $\mathrm{P}<0.05$.

\section{Fruit Flesh Firmness}

It has been observed that with the MeJA dose increases, the softening of fruit flesh delayed. It was determined that the increase in cold storage duration caused a decrease in the flesh firmness values in all treatments. The maximum decrease in fruit firmness values at the end of the storage was found to be in the control treatment. It has been determined that MeJA treatment has a significant effect on maintaining fruit firmness at cold storage and the effect of MeJA treatment changes depending on the concentration and the effectiveness increases with increases in application concentrations (Table 2).

\section{Solible Solids Content (SSC)}

Fruits with high SSC ratio were harvested from MeJA treated trees, but the difference in SSC at harvest between MeJA dose was not significant. Considering the cold storage durations, it was determined that the rates of SSC increased up to 120 days, and then decreased. While the MeJA application is effective in changes in SSC in storage, this effect causes the values to decrease at the $60^{\text {th }}$ and $120^{\text {th }}$ days of storage and increase at the end of storage (Table 3 ). 
Table 2. Effects of pre-harvest MeJA treatments on fruit flesh firmness of Fuji apples.

Çizelge 2. Fuji elmasının meyve eti sertliği üzerine hasat öncesi MeJA uygulamalarının etkisi.

\begin{tabular}{|c|c|c|c|c|}
\hline \multirow{2}{*}{ MeJA treatments } & \multicolumn{4}{|c|}{ Fruit flesh firmness (N) } \\
\hline & Harvest & 60 & 120 & 180 \\
\hline Control (0 mg L-1) & $69.45 \mathrm{c}$ & $67.65 c$ & $66.38 c$ & $52.32 \mathrm{c}$ \\
\hline $1120 \mathrm{mg} \mathrm{L}^{-1}$ MeJA & $77.69 \mathrm{~b}$ & $76.85 \mathrm{~b}$ & 71.12 b & $69.32 \mathrm{~b}$ \\
\hline $2240 \mathrm{mg} \mathrm{L}^{-1} \mathrm{MeJA}$ & 84.56 a & 82.08 a & $69.00 \mathrm{~b}$ & $68.34 \mathrm{~b}$ \\
\hline $4480 \mathrm{mg} \mathrm{L}^{-1} \mathrm{MeJA}$ & 86.79 a & $84.37 \mathrm{a}$ & $77.17 \mathrm{a}$ & $75.21 \mathrm{a}$ \\
\hline
\end{tabular}

The means with the same letter do not differ according to Duncan's multiple range test, $\mathrm{P}<0.05$.

Table 3. Effects of pre-harvest MeJA treatments on SSC of Fuji apples.

Çizelge 3. Fuji elmasının SÇKM içeriği üzerine hasat öncesi MeJA uygulamalarının etkisi.

\begin{tabular}{ccccc}
\hline \multirow{2}{*}{ MeJA treatments } & \multicolumn{4}{c}{ SSC (\%) } \\
\cline { 2 - 5 } & Harvest & $\mathbf{6 0}$ & $\mathbf{1 2 0}$ & $\mathbf{1 8 0}$ \\
\hline Control (0 g L L$\left.^{-1}\right)$ & $13.7 \mathrm{a}$ & $14.7 \mathrm{a}$ & $15.5 \mathrm{a}$ & $13.1 \mathrm{~b}$ \\
$\mathbf{1 1 2 0} \mathbf{~ m g ~ L}^{-1}$ MeJA & $13.0 \mathrm{~b}$ & $14.1 \mathrm{~b}$ & $14.4 \mathrm{~b}$ & $13.7 \mathrm{a}$ \\
$\mathbf{2 2 4 0} \mathbf{~ m g ~ L}^{-1}$ MeJA & $13.1 \mathrm{~b}$ & $13.2 \mathrm{c}$ & $15.8 \mathrm{a}$ & $13.8 \mathrm{a}$ \\
$\mathbf{4 4 8 0} \mathbf{~ m g ~ L}^{-1}$ MeJA & $12.9 \mathrm{~b}$ & $14.0 \mathrm{~b}$ & $14.6 \mathrm{~b}$ & $13.7 \mathrm{a}$ \\
\hline
\end{tabular}

The means with the same letter do not differ according to Duncan's multiple range test, $\mathrm{P}<0.05$

\section{Titratable Acidity}

When the values of measurable acidity measurements after harvest and during storage were examined, it was determined that there was no statistically a significant difference between control and treatment of $1120 \mathrm{mg} \mathrm{L}^{-1}$ MeJA at harvest and at $60^{\text {th }}$ and $120^{\text {th }}$ days of storage, and only at the $180^{\text {th }}$ day of cold storage a difference was observed. However, with MeJA treated at concentrations of 2240 $\mathrm{mg} \mathrm{L}^{-1}$ and $480 \mathrm{mg} \mathrm{L}^{-1}$, it was determined that the titratable acidity values were increased and the acid content at cold storage was maintained. As a result of the analysis during cold storage period, the increase in the duration cold storage leads to a decrease in the ratio of titratable acidity (Table 4 ).

Table 4. Effects of pre-harvest MeJA treatments on titratabale acidity content of Fuji apples.

Çizelge 4. Fuji elmasının titre edilebilir asitlik içeriği üzerine hasat öncesi MeJA uygulamalarının etkisi.

\begin{tabular}{ccccc}
\hline \multirow{2}{*}{ MeJA treatments } & \multicolumn{4}{c}{ Titratabale acidity (\% malic acid) } \\
\cline { 2 - 5 } & Harvest & $\mathbf{6 0}$ & $\mathbf{1 2 0}$ & $\mathbf{1 8 0}$ \\
\hline Control (0 $\left.\mathbf{~ m g ~ L}^{-1}\right)$ & $0.42 \mathrm{~b}$ & $0.37 \mathrm{~b}$ & $0.31 \mathrm{~b}$ & $0.23 \mathrm{~b}$ \\
$\mathbf{1 1 2 0} \mathbf{~ m g ~ L}^{-1} \mathbf{~ M e J A}$ & $0.41 \mathrm{~b}$ & $0.39 \mathrm{~b}$ & $0.30 \mathrm{~b}$ & $0.27 \mathrm{a}$ \\
$\mathbf{2 2 4 0} \mathbf{~ m g ~ L}^{-1} \mathbf{~ M e J A}$ & $0.48 \mathrm{a}$ & $0.45 \mathrm{a}$ & $0.35 \mathrm{a}$ & $0.30 \mathrm{a}$ \\
$\mathbf{4 4 8 0} \mathbf{~} \mathbf{~ g ~ L}^{-1} \mathbf{M e J A}$ & $0.52 \mathrm{a}$ & $0.44 \mathrm{a}$ & $0.36 \mathrm{a}$ & $0.29 \mathrm{a}$ \\
\hline
\end{tabular}

The means with the same letter do not differ according to Duncan's multiple range test, $\mathrm{P}<0.05$.

\section{pH}

When it was compared to the control treatment, it has been determined that the $\mathrm{pH}$ values obtained at the harvest or at the end of the cold storage were lower in the fruits treated with MeJA. It has been found that an increase in the $\mathrm{pH}$ values of all treatments in proportion to the cold storage durations occurred and that increase was higher in the control treatment (Table 5).

Table 5. Effects of pre-harvest MeJA treatments on $\mathrm{pH}$ value of Fuji apples.

Çizelge 5. Fuji elmasının pH değeri üzerine hasat öncesi MeJA uygulamalarının etkisi.

\begin{tabular}{ccccc}
\hline \multirow{2}{*}{ MeJA treatments } & \multicolumn{4}{c}{$\mathbf{p H}$} \\
\cline { 2 - 5 } & Harvest & $\mathbf{6 0}$ & $\mathbf{1 2 0}$ & $\mathbf{1 8 0}$ \\
\hline Control (0 $\left.\mathbf{~ m g ~ L}^{-1}\right)$ & $3.96 \mathrm{a}$ & $4.06 \mathrm{~b}$ & $4.38 \mathrm{a}$ & $4.79 \mathrm{a}$ \\
$\mathbf{1 1 2 0} \mathbf{~ m g ~ L}^{-1}$ MeJA & $3.87 \mathrm{~b}$ & $4.07 \mathrm{~b}$ & $4.26 \mathrm{~b}$ & $4.51 \mathrm{~b}$ \\
$\mathbf{2 2 4 0} \mathbf{~ m g ~ L}^{-1} \mathbf{~ M e J A}$ & $3.85 \mathrm{~b}$ & $4.18 \mathrm{a}$ & $4.29 \mathrm{~b}$ & $4.52 \mathrm{~b}$ \\
$\mathbf{4 4 8 0} \mathbf{~ m g ~ L}^{-1} \mathbf{M e J A}$ & $3.87 \mathrm{~b}$ & $4.16 \mathrm{a}$ & $4.28 \mathrm{~b}$ & $4.56 \mathrm{~b}$ \\
\hline $1=100 \%$ starch and 8 $=0 \%$ starch. The means with the same letter do not \\
differ according to Duncan's multiple range test, $\mathrm{P}<0.05$.
\end{tabular}

\section{Starch Index}

In the analyses made at harvest, the effect of 1120 mg $\mathrm{L}^{-1}$ MeJA on starch index was not significant, whereas with $2240 \mathrm{mg} \mathrm{L}^{-1}$ MeJA and $4480 \mathrm{mg} \mathrm{L}^{-1}$ MeJA, the amount of starch decreased. Retention of fruits in storage has led to an increase in the starch index. It has been determined that there were significant differences in starch index values between treatments on the $60^{\text {th }}$ day of storage. The highest value was obtained by application of $2240 \mathrm{mg} \mathrm{L}^{-1}$ MeJA, while the lowest value was recorded with $1120 \mathrm{mg} \mathrm{L}^{-1}$ MeJA. However, no statistically significant difference was found between $4480 \mathrm{mg} \mathrm{L}^{-1}$ MeJA and control treatments. On the $120^{\text {th }}$ and $180^{\text {th }}$ days of cold storage, it had been determined that there was no difference between the treatments in terms of starch quantities (Table 6).

Table 6. Effects of pre-harvest MeJA treatments on starch index of Fuji apples.

Çizelge 6. Fuji elmasının nişasta indeksi üzerine hasat öncesi MeJA uygulamalarının etkisi.

\begin{tabular}{lcccc}
\hline MeJA treatments & \multicolumn{4}{c}{ Starch index ${ }^{\mathbf{y}}$} \\
\cline { 2 - 5 } & Harvest & $\mathbf{6 0}$ & $\mathbf{1 2 0}$ & $\mathbf{1 8 0}$ \\
\hline Control (0 $\left.\mathbf{~ m g ~ L}^{-1}\right)$ & $6.0 \mathrm{a}$ & $7.0 \mathrm{~b}$ & $8.0 \mathrm{a}$ & $8.0 \mathrm{a}$ \\
$\mathbf{1 1 2 0} \mathbf{~ m g ~ L}^{-1} \mathbf{M e J A}$ & $6.2 \mathrm{a}$ & $6.3 \mathrm{c}$ & $8.0 \mathrm{a}$ & $8.0 \mathrm{a}$ \\
$\mathbf{2 2 4 0} \mathbf{~ m g ~ L}^{-1} \mathbf{M e J A}$ & $5.5 \mathrm{~b}$ & $8.0 \mathrm{a}$ & $8.0 \mathrm{a}$ & $8.0 \mathrm{a}$ \\
$\mathbf{4 4 8 0} \mathbf{~ m g ~ L}^{-1} \mathrm{MeJA}$ & $4.0 \mathrm{c}$ & $7.3 \mathrm{~b}$ & $8.0 \mathrm{a}$ & $8.0 \mathrm{a}$ \\
\hline
\end{tabular}

y $1=100 \%$ starch and $8=0 \%$ starch. The means with the same letter do not differ according to Duncan's multiple range test, $\mathrm{P}<0.05$. 


\section{DISCUSSION}

After harvest, the weight loss due to water loss in fruit leads to significant economic losses by affecting the structure and the appearance of the fruit. In the study we have done to minimize the losses that may occur at cold storage, it was determined that the weight loss of the fruit was increased during cold storage. Similar to our results, Veravrbeke et al. (2003) found that an increase in postharvest cold storage duration increased the weight loss of the fruit, and that the loss varied depending on the amount of waxy layer on the fruit surface and chemical structure of the fruit. Gavalheiro et al. (2003) reported that the waxy layer could maintain its strength until the $90^{\text {th }}$ day after harvest, and that the wax layer was damaged and the losses increased after 120 days of cold storage. In the study which was conducted with an expectation that MeJA may enhance the resistance mechanism of the plant and contribute to the amount and chemical content of the wax layer, it was observed that MeJA treatment has not been effective in preventing weight loss at cold storage. Fujita et al. (2006) and Wasternack (2007) reported that jasmonates (methyl jasmonate and jasmonic acid) are multifunctional compounds that play a role in critical processes associated with biotic and abiotic stress response as well as plant development. Jasmonates are able to elicit protective effects against the plant stress by reducing hydrogen peroxide $\left(\mathrm{H}_{2} \mathrm{O}_{2}\right)$ and malondialdehyde (MDA) levels and increasing antioxidant capacity in plants (Maksymiec and Krupa 2002; Piotrowska et al., 2009; Kovacik et al., 2011; Dar et al., 2015). Hentrich et al. (2013) have found that jasmonates promote auxin (IAA) biosynthesis. Fruit firmness is the most significant fruit quality characteristic that is effective at cold storage.Quality fruit is the first condition for maintaining fruit firmness at cold storage, but it is impossible to maintain the fruit quality obtained at harvest until the end of cold storage. The storage period can be extended by minimizing fruit firmness loss by preharvest and postharvest applications. In the study, which was carried out towards this aim, higher quality fruit at harvest has been achieved by preharvest MeJA treatment. It was determined that MejA was effective in maintaining fruit firmness at cold storage, the effect of MeJA treatment changes depending on the concentration and the increase in concentration also increased the effectiveness. Karaman et al. (2013) reported that MeJA applied 2 weeks before harvest did not affect the fruit firmness, but after 28 days of the cold storage MeJA treated plums remained firmer than controls. (Martinez-Espla et al., 2014), has determined that preharvest MeJA treatments resulted in firmer fruits at time of harvest in 'Black Splendor' and 'RoyalRosa' plums.

Methyl jasmonate (MeJA) is a natural plant growth regulator with a great role played in plant growth, development and resistance to environmental stressors (Rudell et al., 2002; Kondo 2005). MeJA has significant effects on physical (size, color, firmness) and chemical (pH, SSC, TA) characteristics and pigment contents of fruits (Ozturk et al., 2013). JAs treatments positively effect fruit quality characteristics in many fruit (Rohwer and Erwin 2008). Perez et al. (1993) reported that JA stimulated carotene synthesis in tomato, and (Rudell and Mattheis 2008) have determned that exgenous JAs led to phenolic compound (anthocyanin) accumulation. Furtermore, JAs promoted volatile emission in apple (Kondo et al., 2005) and has an effect on fruit quality and antioxidant capacity in blackberry (Wang et al., 2009). MartinezEspla et al. (2014), have reported that preharvest MeJA treatments led to fruit with higher size and weight, firmness and TA at time of harvest in 'Black Splendor' and 'RoyalRosa' plums, and the phenolic content and antioxidant activity were also higher in treated than in control fruit during the last 3 weeks of fruit development in both plum cultivars.

In the study, in which fruits with higher ratio of SSC were harvested by MeJA treatment, MeJA has had an effect on changes that occur in SSC at cold storage. It was determined that MeJA treatment increased the titratable acidity values and had an effected on maintaining the acid content at cold storage. It has been determined that the effect of MeJA on the starch index is not significant, and $\mathrm{pH}$ values were lower in MeJA treatment.

\section{CONCLUSION}

As a result of the study, MeJA application significantly reduced the quality losses at cold storage. With MeJA treatment, the softening of fruit is delayed significantly. As a result, it is determined that the fruit firmness loss that occurs during cold storage can be delayed by MeJA treatment.

\section{REFERENCES}

Blanpied GD and Silsby KJ., 1992. Prediction of harvest date windows for apples. Cornell Cooperation Extension Bulletin, 2212: 1-12.

Cao S.F., Zheng YH., Yang ZF., Tang SS and Jin P., 2008. Control of anthracnose rot and quality deterioration in 
loquat fruit with methyl jasmonate. Journal of Science of Food and Agriculture, 88: 1598-1602.

Castillo S., Navarro D., Zapata PJ., Guillén F, Valero D, Serrano $M$ and Martínez-Romero D., 2010. Antifungal efficacy of Aloe vera in vitro and its use as a preharvest treatment to maintain postharvest table grape quality. Postharvest Biology and Technology, 57: 183-188.

Creelman RA and Mullet JE., 1997. Biosynthesis and action of jasmonate in plants. Ann. Rev. Plant Physiology. Plant Molecular Biology, 488: 355-381.

Dar TA., Uddin M., Khan MMA., Hakeem KR and Jaleel $H_{\text {., }}$ 2015. Jasmonates counter plant stress: a review. Environmental and Experimental Botany, 115: 49-57.

Einhorn TC., Wang Y and Turner J., 2013. Sweet cherry firmness and postharvest quality of late-maturing cultivars are improved with low-rate single applications of gibberellic acid. HortScience, 48: 1010-1017.

Fujita M., Fujita Y., Noutoshi Y., Takahashi F., Narusaka Y., Yamaguchi-Shinozaki K and Shinozaki K., 2006. Crosstalk between abiotic and biotic stress responses: a current view from the points of convergence in the stress signaling networks. Curr. Opin. Plant Biology, 9: 436-442.

Gavalheiro OJ., Santos A., Recasens I., Larrigancliere C and Silvestre A., 2003. Quality of the postuguese Bravo de Esmolfe apple after normal cold storage or controlled atmosphere and two shelf life periods. Acta Horticulturea, 628: 395-400.

Giacalone G and Chiabrando V., 2013. Modified atmosphere packaging of sweet cherries with biodegradable films International Food Research Journal, 20: 1263-1268.

Gimenez MJ., Valverde JM., Valero D., Guillen F., MartinezRomero D., Serano M and Castillo S., 2014. Quality and antioxidant properties on sweet cherries as affected by preharvest salicylic and acetylsalicylic acids treatments. Food Chemistry, 160: 226-232

Gimenez MJ., Valverde JM., Valero D., Díaz-Mula HM., Zapata PJ., Serrano M., Moral J and Castillo S., 2015. Methyl salicylate treatments of sweet cherry trees improve fruit quality at harvest and during storage. Scientia Horticulturae, 197: 665-673.

Gimenez MJ., Serrano M., Valverde JM., Martínez-Romero D., Castillo S., Valero D and Guillén F., 2017. Preharvest salicylic acid and acetylsalicylic acid treatments preserve quality and enhance antioxidant systems during postharvest storage of sweet cherry cultivars. Journal of the Science of Food Agriculture, 97: 1220-1228.

Hentrich M., Böttcher C., Düchting P., Cheng Y., Zhao Y., Berkowitz O., Masle J., Medina J and Pollmann S., 2013. The jasmonic acid signaling pathway is linked to auxin homeostasis through the modulation of YUCCA8 and YUCCA9 gene expression. Plant Journal, 74: 626-637.

Karaman S., Ozturk B., Genc N and Celik SM., 2013. Effect of preharvest application of methyl jasmonate on fruit quality of plum (Prunus salicina Lindell cv. "Fortune") at harvest and during cold storage. Journal Food Processing and Preservation, 37: 1049-1059.

Kondo S., Setha S., Rudell DR., Buchanan, DA and Mattheis JP., 2005. Aroma volatilebiosynthesis in apple affected by 1-MCP and methyl jasmonate. Postharvest Biology and Technology, 36: 61-68.

Kovacik J., Klejdus B., Štork F., Hedbavny J and Backor M., 2011. Comparison of methyl jasmonate and cadmium effect on selected physiological parameters in Scenedesmus quadricauda (chlorophyta, chlorophyceae). Journal of Phycology, 47: 1044-1049.

Kucuker E and Ozturk B., 2015. The effects of aminoethoxyvinylglycine and methyl Jasmonate on bioactive compounds and fruit quality of 'North Wonder' sweet cherry. African Journal of Traditional Complementary and Alternative Medicines, 12: 114-119.

Maksymiec W and Krupa Z., 2002. Jasmonate and heavy metals in Arabidopsis plants-a similar physiological response to both stressors? Jornal of Plant Physiology, 159: 509-515.

Martínez-Esplá, A., Zapata PJ., Castillo S., Guillén F., MartínezRomero D., Valero D and Serrano M., 2014. Preharvest application of methyl jasmonate (MeJA) in twoplum cultivars. 1. Fruit growth and quality attributes at harvest. Postharvest Biology and Technology, 98: 98-105.

Meheriuk M., Girard B., Moyls L., Beveridge HJT., McKenzie DL., Harrisson J., Weintraub S and Hocking R., 1995. Modified atmosphere packing of lapins sweet cherry. Food Research International, 28: 239-244.

Moline HE., Buta JG., Saftner RA and Maas JL., 1997. Comparison of three volatile natural products for the reduction of postharvest decay in strawberries. Advances in Strawberry Research, 16: 43-48.

Ozkan Y., Ucar M., Yildiz K and Ozturk B., 2016. Pre-harvest gibberellic acid (GA3) treatments play an important role on bioactive compounds and fruit quality of sweet cherry cultivars. Scientia Horticulturae, 211: 358-362.

Ozturk B., Altuntas E., Yildiz K., Ozkan Y and Saracoglu O., 2013. Effect of methyl jasmonate treatments on the bioactive compounds and physicochemical quality of 'Fuji' apples. Ciencia e Investigación Agraria, 40: 201-211.

Özgen M., Serçe S., Akça Y and Hong JH., 2015. Lysophosphatidylethanolamine (LPE) improves fruit size color, quality and phytochemical contents of sweet cherry cv. '0900 Ziraat'. Korean Journal of Horticultural and Science, 33: 196-201.

Öztürk B., Yıldız K., Uzun S and Öztürk A., 2017. Effects of Pre-Harvest AVG Treatments on Fruit Quality of Jonagold Apple Cultivar throughout Cold Storage. International Journal of Agricultural and Wildlife Siences, 3(1): 1-5.

Pena-Cortés H., Barrios P., Dorta F., Polanco V., Sánchez C., Sánchez E and Ramírez I., 2005. Involvement of jasmonic acid and derivatives in plant responseto pathogen and insects and in fruit ripening. Journal Plant of Growth 
Regulation, 23: 246-260.

Pérez AG., Sanz C., Richardson DG and Olías JM., 1993. Methyl jasmonate vaporpromotes B-carotene synthesis and chlorophyll degradation in goldendelicious apple peel. Journal Plant of Growth Regulation, 12(3): 163-167.

Petracek PD., Joles DW., Shirazi A and Cameron AC., 2002. Modified atmosphere packaging of sweet cherry (Prunus avium L. ev.'Sams') fruit: metabolic responses to oxygen, carbon dioxide, and temperature. Postharvest Biology and Technology, 24: 259-270.

Piotrowska A., Bajguz A., Godlewska- Zyłkiewicz B., Czerpak $\mathrm{R}$ and Kaminska M., 2009. Jasmonic acid as modulator of lead toxicity in aquatic plant Wolffia arrhiza (Lemnaceae). Environmental and Experimental Botany, 66: 507-513.

Ragsdale NN and Sisler HD., 1994. Social and political implications of managing plant diseases with decreased availability of fungicides in the United States. Annual Review of Phytopathology, 32, 545-557.

Rohwer CL and Erwin GE., 2008. Horticultural application of jasmonates. Journal of Horticultural Science and Biotechnology, 83: 283-304.

Rudell DR and Mattheis JP., 2008. Synergism exists between ethylene and methyljasmonate in artificial light-induced pigment enhancement of 'fuji' apple fruit peel. Postharvest Biology and Technology, 47(1): 136-140.

Rudell DR., Mattheis JP., Fan X and Fellman JK., 2002. Methyl jasmonate enhances anthocyanin accumulation and modifies production of phenolics and pigments in 'Fuji' apples. Journal of the American Society for Horticultural Science, 127: 435-441.

Sayyari M., Babalar M., Kalantari S., Martínez-Romero D., Guillén F., Serrano M and Valero D., 2011. Vapour treatments with methyl salicylate or methyljasmonate alleviated chilling injury and enhanced antioxidant potential during postharvest storage of pomegranates. Food Chemistry, 124: 964-970.

Tzortzakis NG., 2007. Methyl jasmonate-induced suppression of anthracnose rot in tomato fruit. Crop Protection, 26: 1507-1513.
Valero D., Diaz-Mula HM., Zapata PJ., Castillo S., Guillen F., Martinez-Romero D and Serrano M., 2011. Postharvest treatments with salicylic acid, acetylsalicylic acid or oxalic acid delayed ripening and enhanced bioactive compounds and antioxidant capacity in sweet cherry. Journalof Agricultural and Food Chemistry, 59: 54835489.

Valero D., Mirdehghan SH., Sayyari M and Serrano M., 2014. Vapor treatments, chilling, storage, and antioxidants in pomegranates. In: Preedy, V.R. (Ed.), Processing and Impact on Active Components in Food. Academic Press, London, pp. 189-196.

Valverde JM., Giménez MJ., Guillén F., Valero D., MartínezRomero D and Serrano M., 2015. Methyl salicylate treatments of sweet cherry trees increase antioxidant systems in fruit at harvest and during storage. Postharvest Biology and Technology, 109: 106-113.

Wang K., Jin P., Cao S., Shang H., Yang Z and Zheng Y., 2009. Methyl jasmonate reduces decay and enhances antioxidant capacity in Chinese bayberries. Journal of Agricultural Food Chemistry, 57: 5809-5815.

Wasternack C., 2007. Jasmonates: an update on biosynthesis, signal transduction and action in plant stress response, growth and development. Annals of Botany, 100: 681697.

Veravrbeke EA., Verboven P., Oostveldt P and Nicolai BM., 2003. Predication of moisture loss across the cuticle of apple (Malus sylvestris supsp. Mitis (Wallr.) during storage: part 2. Model simulations and practical applications. Postharvest Biology and Technology, 30: 89-97.

Yao HJ and Tian SP., 2005. Effects of pre- and post-harvest application of salicylic acid or methyl jasmonate on inducing desease resistance of cherry fruit in storage. Postharvest Biology and Technology, 35: 253-262.

Zhang C and Whitting M., 2011. Pre-harvest foliar application of prohexadione-Ca and gibberellins modify canopy source-sink relations and improve quality and shelf- life of 'Bing' sweet cherry. Plant Growth Regulation, 65: 145-156. 